\title{
THE HEATING LOAD DETERMINATION OF LOW ENERGY BUILDINGS IN NORTHERN CLIMATE
}

\author{
Nerijus Venckus ${ }^{1}$, Raimondas Bliūdžius ${ }^{2}$, Jurga Poderyté ${ }^{3}$, Arūnas Burlingis ${ }^{4}$ \\ ${ }^{1,3}$ Department of Civil Engineering and Architecture, Kaunas University of Technology, \\ Studentu g. 48, LT-51367 Kaunas, Lithuania \\ ${ }^{2,4}$ Institute of Architecture and Construction, Kaunas University of Technology, \\ Tunelio g. 60, LT-44405 Kaunas, Lithuania \\ E-mails: ${ }^{1}$ venckus.nerijus@gmail.com; ${ }^{2}$ raimondas.bliudzius@ktu.lt (corresponding author); \\ ${ }^{3}$ jurga.poderyte@ktu.lt; ${ }^{4}$ arunas.burlingis@asi.lt \\ Received 03 Jan. 2012; accepted 01 Jun. 2012
}

\begin{abstract}
Low energy buildings require an efficient thermal insulation of the envelopes ensuring minor heat losses; such buildings must be tight in order to avoid heat losses due to over-infiltration. Installation of a heating recovery system compensates for some heat used for heating the ventilation air. The design solution of transparent envelopes of low energy buildings determines significant solar heat gains that compensate for a part of heat losses through the envelopes and ventilation systems. Taking into account these properties of low energy buildings, the modeling of indoor temperatures of such building was carried out at varying outdoor temperatures and power of the heating system. On the grounds of the obtained results, it was determined that a lower heat source power than the one determined according to the outdoor temperature of the coldest five-day period can be used to meet the indoor microclimate requirements in a low energy building. In this way, the expenses of heating system installation are reduced and the operational efficiency of the heat source is increased.
\end{abstract}

Keywords: low energy building, heat recovery system, internal heat load, air tightness, thermal energy consumption, energy saving.

\section{Introduction}

The lowest outdoor temperatures reached during the heating season are used for the calculation of heating load of conventional building. The heat source power of more substantial buildings (the weight of their envelopes does not exceed $100 \mathrm{~kg} / \mathrm{m}^{2}$ ) is estimated according to the temperature of the coldest five-day period, whereas for lightweight buildings the coldest daily temperature is used (STR 2.09.04:2008, Appendix 3, Table 3.1). Considering the purpose of the building and the desired level of comfort, these temperatures may differ as normative documents present them on a different level of reliability (RSN 156-94 1995). When the power of the heat sources used for heating buildings is calculated according to the lowest outdoor temperatures, constant indoor temperature is ensured in the buildings. However, the installation of high-power heating systems increases the costs of construction and at the same time reduce the economical load of the under-loaded boiler (Gimbutis et al. 1993; Ramesh, Dušan 2003; Švenčianas, Adomavičius 2011).

Heat loss through the envelopes in low energy buildings is much lesser than in conventional buildings: the former ones are tight and for this reason no heat is lost due to over-infiltration (Juodis et al. 2009). A great amount of thermal energy used for heating the ventilation air is restored having installed a heat recovery system (Chlela et al. 2009). As the outdoor temperature is varied, the change of indoor temperature of low energy buildings is slower (Ghiaus, Hazyuk 2010; Hens et al. 2010). Therefore, most probably the use of heating systems based on the lowest temperatures of the heating season is not required in order to ensure indoor microclimate conditions (Yang et al. 2011). This could reduce the costs of heating system installation and increase the efficiency of the system in operation without worsening the indoor microclimate conditions in the buildings. Some of the researchers made studies in determining heating load for the residential buildings by selecting optimal thickness of the buildings thermal envelope (Daouas 2011), developing complex heating load determination programs using standard calculations (Petersen, Svendsen 2010; Ogonowski 2010) but also there is lack of the outdoor temperature determination used in heating load calculations in Lithuanian climate. For this purpose a research on the indoor temperature variation of a low energy building was carried out seeking to develop a heating load calculation method of the heating systems in such buildings.

\section{Factors affecting heating load demand of low energy buildings}

One of the advantages of low energy buildings is the stability of indoor microclimate conditions (Feist et al. 2005). This index depends on the following: thermal inertia of partitions (Catalina et al. 2008), the level of thermal insula- 
tion of envelopes, tightness of the building, an efficiency of heating and ventilation systems, indoor temperature and allowable limits of its variation, as well as the lowest outdoor temperatures and their periodical duration. The lesser are the heat losses through the envelopes, the greater is the impact of internal and solar heat gains on the thermal balance of the whole building; this is why the gains should not be left out from the calculation of the heating load of buildings (Oliveti et al. 2011). Having evaluated these gains and the properties of low energy buildings, both the overall demand for thermal energy for heating and the demand for the highest heating load, calculated according to the lowest outdoor temperatures, are diminished.

\subsection{Technical properties of low energy buildings}

Design documentation of a low energy (passive) building constructed in 2009 is employed for the present research. The article (Venckus et al. 2010) provides a detailed discussion on constructional and energy properties of the building, whereas Table 1 presents geometrical and Table 2 - energy properties of the analyzed building. For the construction of envelopes, ceramic blocks, concrete and reinforced concrete as well as thermal insulation layers on the outside were used. In order to calculate the heating load of this building following STR 2.09.04:2008 (2008), the selected temperature must not exceed the temperature of the coldest five-day period. This is because the envelopes of the building belong to the group having external walls which weight $>100 \mathrm{~kg} / \mathrm{m}^{2}$, internal partitions - $50 \div$ $100 \mathrm{~kg} / \mathrm{m}^{2}$, floors and ceilings $->150 \mathrm{~kg} / \mathrm{m}^{2}$ (STR 2.09.04:2008; Appendix 3, Table 3.1). Following the methodology in STR 2.09.04:2008 (2008), this building should be equipped with a heating source of $7.81 \mathrm{~kW}$ power.

Table 1. Geometrical properties of the building used for modeling of dynamics of indoor temperature

\begin{tabular}{|c|c|c|c|}
\hline \multicolumn{4}{|c|}{ Areas of construction surfaces of the building, $\mathrm{m}^{2}$} \\
\hline $\begin{array}{c}\text { Area of external } \\
\text { walls }\end{array}$ & 262.8 & Area of floor & 96.2 \\
\hline Area of partitions & 178.6 & Area of ceiling & 96.2 \\
\hline $\begin{array}{l}\text { Area of transpa- } \\
\text { rent fenestrations }\end{array}$ & 59.5 & \multirow{2}{*}{$\begin{array}{l}\text { Area of furniture } \\
\text { surface for square unit } \\
\text { of the floor, } \mathrm{m}^{2} / \mathrm{m}^{2}\end{array}$} & \multirow[t]{2}{*}{$0.5^{*}$} \\
\hline Area of the roof & 130.6 & & \\
\hline
\end{tabular}

Table 2. Energy properties of the building

\begin{tabular}{|c|c|c|c|}
\hline $\begin{array}{l}\text { Average thermal } \\
\text { transmittance of non- } \\
\text { transparent areas of } \\
\text { envelope, } \mathrm{W} / \mathrm{m}^{2} \mathrm{~K}\end{array}$ & 0.115 & $\begin{array}{l}\text { Thermal capacity } \\
\text { of external walls, } \\
\mathrm{MJ} / \mathrm{K}\end{array}$ & 17.84 \\
\hline $\begin{array}{l}\text { Average thermal } \\
\text { transmittance of } \\
\text { transparent areas of } \\
\text { envelope, } \mathrm{W} / \mathrm{m}^{2} \mathrm{~K}\end{array}$ & 0.79 & $\begin{array}{l}\text { Thermal capacity } \\
\text { of internal parti- } \\
\text { tions, } \mathrm{MJ} / \mathrm{K}\end{array}$ & 34.29 \\
\hline $\begin{array}{l}\text { Air change rate of the } \\
\text { building at } 50 \mathrm{~Pa} \\
\text { pressure difference, } \mathrm{h}^{1}\end{array}$ & 0.39 & $\begin{array}{l}\text { Time constant of } \\
\text { active internal } \\
\text { surfaces, } h\end{array}$ & 277 \\
\hline \multicolumn{3}{|c|}{ Internal heat gains, $\mathrm{W} / \mathrm{m}^{2}$ (Feist et al. 2005) } & 2.1 \\
\hline
\end{tabular}

\subsection{Indoor temperature and allowable limits of its variation in the modeled building}

According to the Lithuanian standard HN 42:2009 "Microclimate in dwellings and public buildings" (2009) and international (ISO 7730:2005) requirements, the conditions of thermal comfort in dwellings correspond to $20 \div 24{ }^{\circ} \mathrm{C}$ temperature variation interval, while sufficient conditions are $18 \div 26^{\circ} \mathrm{C}$ during the cold season of the year. The document CR 1752 of the European Committee for Standardization (1998) states that the temperature in the premises fulfilling B conditions has to reach $22 \pm 2{ }^{\circ} \mathrm{C}$. Taking into account the mentioned requirements, a normative temperature of $+22{ }^{\circ} \mathrm{C}$ was selected for the research. The allowable decline of this temperature is no more than $2{ }^{\circ} \mathrm{C}$ to preserve the required comfort conditions in the premises.

\subsection{Lithuanian climate data}

Lithuania belongs to the cold climate zone. Although the average outdoor temperatures during the heating season only slightly differ in Lithuania and Central Europe, the periods with the lowest temperatures possible in Lithuania have the greatest impact on the choice of heating system power. The climate data recorded by meteorological station of Kaunas University of Technology Institute of Architecture and Construction (KTU ASI) show that the lowest temperatures usually occur in fine weather (Figs 1-4). For this reason, greater heat losses through the envelopes are partially compensated by solar heat gains, while in cloudy weather when the intensity of solar radiation decreases, outdoor temperature does not reach the lowest level. Since no generalized data on the intensity of solar radiation depending on outdoor temperatures has been collected yet, the research makes use of the climate data recorded by KTU ASI meteorological station in 2009 and 2010, namely: the outdoor temperature and intensity of solar radiation. To compare the obtained results with the results of the currently-used standard method, a temperature period was composed using the lowest standardized temperatures for calculation together with the impact of solar radiation.

The periods of the lowest temperatures composed on the grounds of KTU ASI meteorological station data:

1. Medium-cold days and period with the least solar radiation in 2009-2010: from 15/12/2009 to $05 / 01 / 2010$, the lowest recorded outdoor temperature: $-14.6^{\circ} \mathrm{C}$, duration: 21 days (Fig. 1);

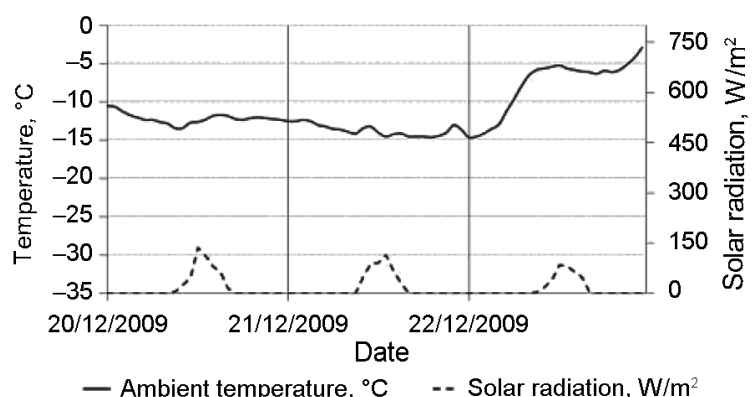

Fig. 1. Medium-cold days and period with the least solar radiation in 2009-2010 
2. The lowest temperature in 2009. Period: 04/01/2009-06/01/2009, the lowest recorded outdoor temperature: $-18.1^{\circ} \mathrm{C}$, duration: 3 days (Fig. 2);

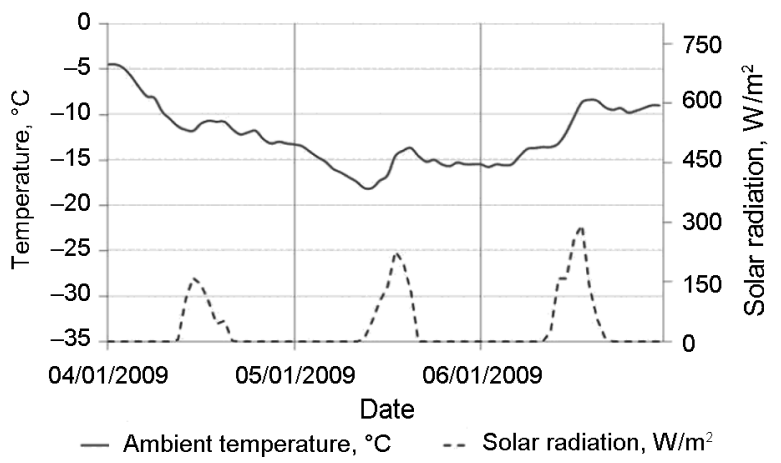

Fig. 2. The lowest temperatures in 2009

3. The lowest temperatures in 2010. Period: $15 / 01 / 2010-02 / 02 / 2010$; the lowest recorded outdoor temperature: $-23.2^{\circ} \mathrm{C}$, duration: 18 days (Fig. 3);

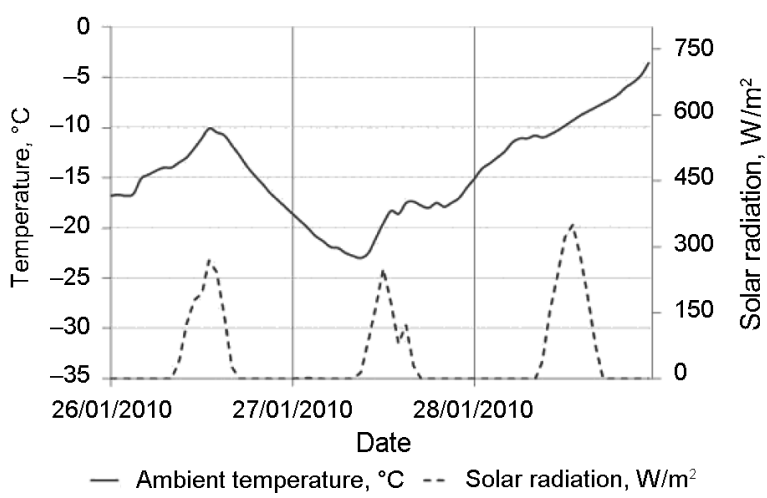

Fig. 3. The lowest temperatures in 2010

4. Theoretically framed period: the coldest theoretically possible five-day period in Kaunas. Average outdoor temperature: $-23.0^{\circ} \mathrm{C}$; for the modeled period, solar radiation was estimated according to the data of KTU ASI meteorological station collected on 15/01/2010-02/02/2010, when the minimal temperature of 2010 was reached $\left(-23.2{ }^{\circ} \mathrm{C}\right)$. Duration of the period: 5 days (Fig. 4).

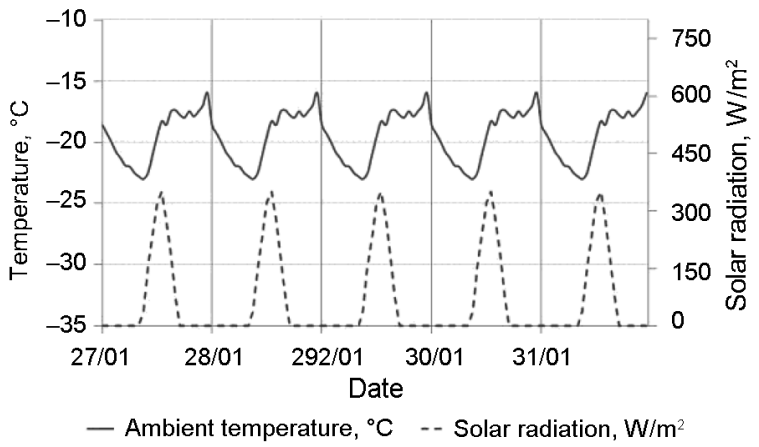

Fig. 4. The coldest theoretically possible five-day period in Kaunas
Having analyzed the climate data and established possible variation limits of indoor temperature in the researched building, a predictive model of indoor temperature variation of substantially low energy buildings was developed. The model is used for estimating the efficient power of the heating system.

\section{Modeling the heat-up and cool down processes of the low energy building}

\subsection{Calculation method}

There were used calculation program to determine the dynamics of indoor air temperatures change in respect of variation of outdoor temperature, solar heat gains, thermal inertia of building envelope and internal mass (partitions, ceiling, floor and furniture). The change of internal air temperature $\Delta T_{\text {air }}$ after receiving of amount of thermal energy $\Delta Q$ is determined as:

$$
\Delta T_{\text {air }}=\frac{\Delta Q}{c_{p} \cdot \rho \cdot V}
$$

where: $\Delta T_{\text {air }}$ - change of air temperature, $\mathrm{K} ; \Delta Q$ - thermal balance of indoor space per each time step, $\mathrm{J} ; c_{p}$ specific thermal capacity of air, $\mathrm{J} /(\mathrm{kg} \cdot \mathrm{K}) ; \rho$ - air density, $\mathrm{kg} / \mathrm{m}^{3} ; V$ - volume of indoor air, $\mathrm{m}^{3}$.

Thermal balance $\Delta Q$ is determined as:

$$
\begin{aligned}
\Delta Q= & Q_{\text {ext }}+Q_{\mathrm{int}}+Q_{w d}+Q_{f l}+Q_{\mathrm{inf}}+Q_{v e n t}+Q_{i h g}+ \\
& Q_{\text {shg }}+Q_{h s},
\end{aligned}
$$

where: $Q_{e x t}$ - amount of thermal energy from (through) surfaces of non-transparent areas of envelope (excluding floor), J; $Q_{\text {int }}$ - amount of thermal energy from surfaces of internal partitions and furniture, $\mathrm{J} ; Q_{w d}$ - amount of thermal energy from (through) transparent areas of the envelope, J; $Q_{f l}$ - amount of thermal energy though the ground, (are taken as stable during one month period, calculated according to STR 2.05.01:2005 2005), J; $Q_{\text {inf }}$ - amount of thermal energy for air heating due to infiltration through the envelope, J; $Q_{\text {vent }}$ - amount of thermal energy for heating the air supplied through heat recovery system, $\mathrm{J} ; Q_{i n g}$ - amount of thermal energy from internal heat gains (are taken as stable during whole calculation period), J; $Q_{s h g}$ - amount of thermal energy from solar heat gains, J; $Q_{h s}$ - amount of thermal energy from heating system, J.

Calculation of amount of thermal energy from (through) all non-transparent surfaces $\left(Q_{e x t}, Q_{\text {int }}\right)$ takes into account the thermal inertia:

$$
Q_{\text {int, } e x t}=h_{s} \cdot\left(T_{s}-T_{\text {air }}\right) \cdot \Delta z \cdot A_{s},
$$

where: $h_{s}$ - indoor surface heat transfer coefficients of non-transparent envelope and internal partitions and furniture, $\mathrm{W} / \mathrm{m}^{2} \mathrm{~K} ; T_{s}$ - thermodynamic indoor surface temperature, $\mathrm{K} ; T_{\text {air }}$ - thermodynamic indoor air temperature, $\mathrm{K} ; \Delta z$ - time period (calculation time step), s; $A_{s}-$ surface area, $\mathrm{m}^{2}$.

Determination of the indoor surface heat transfer coefficients of non-transparent envelope and internal 
partitions and furniture equivalent was carried out according to:

$$
h_{s}=N u \cdot\left(\frac{\lambda}{s}\right)+\frac{4 \cdot \sigma \cdot\left(\frac{T_{s}+T_{\text {air }}}{2}\right)^{3}}{\frac{1}{\varepsilon_{1}}+\frac{1}{\varepsilon_{2}}-1},
$$

where: $\varepsilon_{i}$ - emissivity of surface; $\sigma=5.67 \cdot 10^{-8}-$ StefanBoltzmann's constant; $s$ - thickness of air boundary layer, $\mathrm{m} ; \mathrm{Nu}$ - Nusselt number calculated according to LST EN 673:2011; $\lambda$ - thermal conductivity of air, $\mathrm{W} /(\mathrm{m} \cdot \mathrm{K})$.

Calculation of temperatures dynamics through the cross-section of enclosure or active surface layer of internal partition and furniture by use of finite difference calculation method is expressed:

$$
t_{n}^{\prime}=t_{n}+\left(\frac{t_{n-1}-t_{n}}{\Delta R_{n-1}}-\frac{t_{n}-t_{n+1}}{\Delta R_{n}}\right) \cdot \frac{2 \cdot \Delta z}{d_{n-1} \cdot c_{n-1} \cdot \gamma_{n-1}+d_{n} \cdot c_{n} \cdot \gamma_{n}},
$$

where: $\Delta z$ - time period (calculation time step), $\mathrm{s} ; d_{n}-$ thickness of layer between " $n$ " and " $n+1$ " planes, m; $c_{n}$ specific thermal capacity of the layer between " $n$ " and " $n+1$ " planes, $\mathrm{J} /(\mathrm{kg} \cdot \mathrm{K}) ; \gamma_{n}$ - material of the layer between " $n$ " and " $n+1$ " planes density, $\mathrm{kg} / \mathrm{m}^{3} ; q_{n(n-1)}-$ potential of heat flow density between " $n$ " and " $n-1$ " planes at the time moment after time period $\Delta z, \mathrm{~W} / \mathrm{m}^{2} ; q_{(n+1) n}$ - heat flow density between " $n$ " and " $n+1$ " planes at the initial time moment $z$, i.e. the heat flow rate due to temperature difference $\left(t_{n}-t_{n+1}\right), \mathrm{W} / \mathrm{m}^{2}$.

The amount of thermal energy from (through) transparent areas of the envelope was calculated neglecting thermal inertia of these elements:

$$
Q_{w d}=U_{w d} \cdot\left(T_{\text {air }}-T_{\text {ext }}\right) \cdot \Delta z \cdot A_{w d},
$$

where: $U_{w d}$ - thermal transmittance coefficient of transparent elements of envelope, $\mathrm{W} / \mathrm{m}^{2} \mathrm{~K} ; T_{\text {ext }}$ - thermodynamic outdoor temperature, $\mathrm{K} ; A_{w d}$ - surface area of transparent elements of envelope, $\mathrm{m}^{2}$.

Thermodynamic outdoor temperature is assumed to change as a cosine wave around its average value. Following this method, the design outdoor temperature $T_{e x t}$ after the period $\Delta z$ is expressed according to Eq. (7) (Fokin 2006):

$$
T_{\text {ext }}=T_{a}+A_{e} \cdot \cos \left(\frac{2 \cdot \pi}{\Delta z} \cdot t\right)
$$

where: $T_{a}$ - average outdoor temperature, $\mathrm{K} ; A_{e}$ - amplitude of outdoor temperature variation, ${ }^{\circ} \mathrm{C} ; \Delta z$ - period of temperature variation, $\mathrm{h} ; t-$ time from the beginning of variation, $h$.

Amount of thermal energy due to infiltration through the envelope was calculated according to:

$$
Q_{\text {inf }}=\frac{c_{p} \cdot \rho \cdot V \cdot\left(T_{\text {air }}-T_{\text {ext }}\right) \cdot n}{3600} \cdot \Delta z
$$

where: $n$ - air change rate of the building due to infiltration through the envelope, $1 / \mathrm{h}$.
Amount of thermal energy for heating the air supplied through heat recovery system:

$$
Q_{\text {vent }}=\frac{1-\eta}{100} \cdot \frac{c_{p} \cdot \rho \cdot\left(T_{\text {air }}-T_{\text {ext }}\right) \cdot L}{3600} \cdot \Delta z,
$$

where: $\eta$ - efficiency of heat recovery system, $\% ; L-$ amount of supplied fresh air through the heat recovery system, $\mathrm{m}^{3} / \mathrm{h}$.

Amount of thermal energy from solar heat gains was calculated using solar radiation estimated according to the data of KTU ASI meteorological station collected on $15 / 01 / 2010-02 / 02 / 2010$ (theoretically framed period, Fig. 4), according to:

$$
Q_{\text {shg }}=\sum q_{s o} \cdot \Delta z \cdot g \cdot A_{g l} \cdot a,
$$

where: $q_{s o}$ - solar heat flow density, recalculated from theoretically framed period taking into account direction of the windows and doors, $\mathrm{W} / \mathrm{m}^{2} ; g-$ solar heat gain coefficient of the glazing; $A_{g l}$ - area of the glazed part of windows and doors, $\mathrm{m}^{2} ; a$-correction due to shading.

Thermal energy from heating system was taken as necessary amount of energy to keep the required air temperature in the premises. When amount of heating energy to reach required temperature in the premises is bigger than maximum heating power, then the maximum heating power energy is taken.

\subsection{Conditions for selecting of optimal peak power of heating system in the building}

When the rates of heating up and cool down (Figs 5 and 6), geometrical and thermal characteristics (Tables 1 and 2) of the building and climatic data on the lowest outdoor temperatures and solar radiation (Figs 1-4) are known, the influence of the outdoor temperature variation on the indoor temperature variation can be forecasted. Such forecasts are invoked to determine the power of the heating system in the building, taking into account the established microclimate requirements of the premises. When the heat losses are lesser than the amount of heat supplied, the premises are assumed to be heated up; conversely, when the heat losses exceed the power supplied by the heat source, the cool down of the premises begins.

A limitation of $22^{\circ} \mathrm{C}$ as the highest temperature of premises was established in the calculations. It can be controlled by an automatic or mechanical temperature regulation thermostats installed in the heating system, which prevent the indoor temperature rising above the set-up temperature ensuring average comfort conditions in the premises.

\subsection{Selection of efficient heating load in the modeling of heating and cooling processes of the premises}

Using the combinations of outdoor temperature and solar radiation, introduced in Section 2.3, the variation of indoor temperature was modeled at different powers of the heating system. The modeling results demonstrated that the greatest indoor temperature variation takes place when the combination of the outdoor temperature of five- 
day period and the respective solar radiation intensity (theoretically framed period, Fig. 4) is used. For this reason, further experiments were carried out using only this combination of climatic parameters. At the beginning, a certain power of the heating system was selected so that the indoor temperature would not drop below $22{ }^{\circ} \mathrm{C}$ (Fig. 5). Next, the power of the heating system was being reduced until the indoor temperature declined to $20^{\circ} \mathrm{C}$ (Fig. 6).

The modeling results showed that the indoor temperature of the low energy building conforms to the limit of the lowest temperature $\left(22^{\circ} \mathrm{C}\right)$ when the power of the heating system is $4.74 \mathrm{~kW}$ (Fig. 5). This power is $39.3 \%$ lesser than the heating load of the building calculated according to STR 2.09.04:2008 (2008) (7.81 kW).

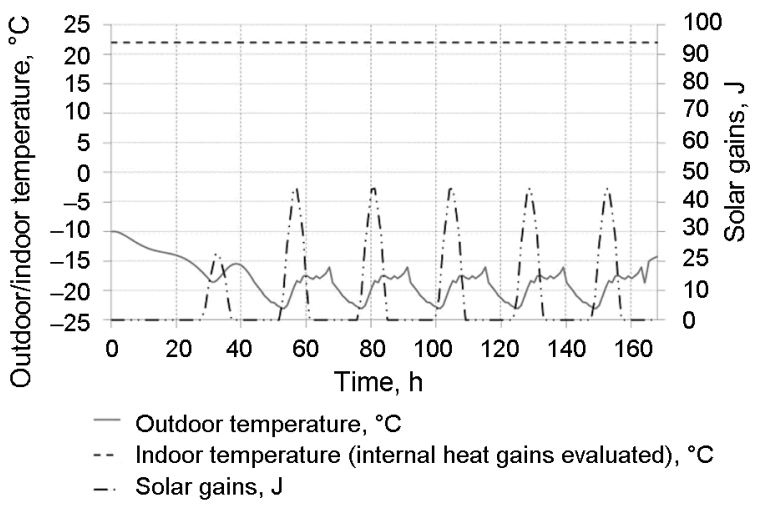

Fig. 5. Dependence of indoor temperature on the peak power of heating system. Period: theoretically framed period, Fig. 4; power: $4.74 \mathrm{~kW}$

When the limit of the lowest allowable temperature is reduced to $20^{\circ} \mathrm{C}$, comfort microclimate conditions are ensured and the calculated power of the heating system decreases to $1.52 \mathrm{~kW}$ (Fig. 6).

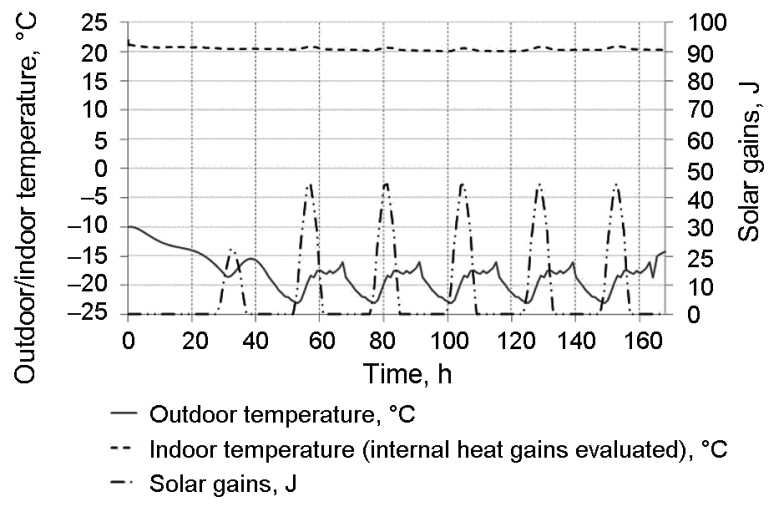

Fig. 6. Dependence of indoor temperature on the peak power of heating system at varying outdoor temperature. Period: theoretically framed period, Fig. 4; power: $1.52 \mathrm{~kW}$

This power is $80 \%$ less than the one calculated according to STR 2.09.04:2008 (2008) and 67.9\% less than the power of the heating system required to ensure the temperature of $22{ }^{\circ} \mathrm{C}$.

\section{Conclusions and recommendations}

The methodology presented in this paper may be applied for the indoor temperature variation forecast of any buildings; however, the most beneficial effect is achieved when it is used for design of heating systems of low energy dwellings. In conventional buildings, heat losses are notably greater than in low energy buildings since in the former, internal and solar heat gains compensate for a smaller amount of heat losses than in low energy buildings, which were designed to make the maximum use of solar energy. The power of the heating system calculated according to the presented methodology is lesser than the one obtained applying standard methods. Therefore, there is a calculation-based possibility of using air heating systems in low energy buildings even under colder climate conditions. The power of such systems is limited by technical (restricted temperature of the supplied air) and hygienic (restricted speed of the air supplied into premises) requirements. On the other hand, it is recommended to install reserve heat sources in low energy buildings that would provide heating in case of a heating-cooling system breakdown. They could also be used in case of extreme low outdoor temperatures, low intensity of solar radiation and internal heat gains.

\section{Conclusions}

1. In substantial low energy buildings, the heating load can be $40-80 \%$ less than the load calculated following standard methods; such load would still ensure the established requirements for the thermal comfort of the building.

2. Lower -power heating systems would operate in nearly-optimal regime during the major part of the heating season; as a result, a higher efficiency of the system would be achieved and the total energy input of the building would decrease.

3. The lowest power of the heating system of the building, ensuring the established indoor microclimate requirements and verified by the calculations according to the presented methodology, allow the efficient use of air and heat recovery systems for heating and cooling, which also contribute to the reduction of total energy consumption of the building.

\section{References}

Catalina, T.; Virgone, J.; Blanco, E. 2008. Development and validation of regression models to predict monthly heating demand for residential buildings, Energy and Buildings 40(10): 1825-1832.

http://dx.doi.org/10.1016/j.enbuild.2008.04.001

Chlela, F.; Husaunndee, A.; Inard, C.; Riederer, P. 2009. A new methodology for the design of low energy buildings, Energy and Buildings 41(9): 982-990.

http://dx.doi.org/10.1016/j.enbuild.2009.05.001

CR 1752 Ventilation for Buildings: Design Criteria for the Indoor Environment. CEN, 1998. 76 p.

Daouas, N. 2011. A study on optimum insulation thickness in walls and energy savings in Tunisian buildings based on analytical calculation of cooling and heating transmission loads, Applied Energy 88(1): 156-164. http://dx.doi.org/10.1016/j.apenergy.2010.07.030 
Feist, W.; Schnieders, J.; Dorer, V.; Haas, A. 2005. Reinventing air heating: convenient and comfortable within the frame of the Passive House concept, Energy and Buildings 37(11): 1186-1203.

http://dx.doi.org/10.1016/j.enbuild.2005.06.020

Fokin, K. F. 2006. Stroitelnaia teplotekhnika ograzhdaiushchikh chastej zdanij. Moskva: AVOK:PRES. $287 \mathrm{~s}$.

Ghiaus, C.; Hazyuk, I. 2010. Calculation of optimal thermal load of intermittently heated buildings, Energy and Buildings 42(8): 1248-1258. http://dx.doi.org/10.1016/j.enbuild.2010.02.017

Gimbutis, G.; Kajutis, K.; Krokunis, V.; Pranckūnas, A.; Švenčiakas, P. 1993. Šlumine technika [Thermotechnics]. Vilnius: Mokslas. $333 \mathrm{p}$.

Hens, H.; Parijs, W.; Deurinck, M. 2010. Energy consumption for heating and rebound effects, Energy and Buildings 42(1): 105-110.

http://dx.doi.org/10.1016/j.enbuild.2009.07.017

HN 42:2009 Gyvenamuju ir visuomeniniu pastatu patalpu mikroklimatas [Microclimate in dwellings and public buildings]. Vilnius, 2009. 4 p.

ISO EN 7730:2005 Moderate thermal environments - Determination of the PMV and PPD indices and specification of the conditions for thermal comfort. International Standards Organisation, Geneva, 2005. 54 p.

Juodis, E.; Jaraminiene, E.; Dudkiewicz, E. 2009. Inherent variability of heat consumption in residential buildings, Energy and Buildings 41(11): 1188-1194. http://dx.doi.org/10.1016/j.enbuild.2009.06.007

LST EN 673:2011 Glass in building - Determination of thermal transmittance (U value) - Calculation method. Lithuanian Standardization Department, 2011. 18 p.

Ogonowski, S. 2010. Modeling of the heating system in small building for control, Energy and Buildings 42(9): 15101516. http://dx.doi.org/10.1016/j.enbuild.2010.03.021

Oliveti, G.; Arcuri, N.; Bruno, R.; De Simone, M. 2011. An accurate calculation model of solar heat gain through gla- zed surfaces, Energy and Buildings 43(2-3): 269-274. http://dx.doi.org/10.1016/j.enbuild.2010.11.009

Petersen, S.; Svendsen, S. 2010. Method and simulation program informed decisions in the early stages of building design, Energy and Buildings 42(7): 1113-1119. http://dx.doi.org/10.1016/j.enbuild.2010.02.002

Ramesh, K. S.; Dušan, P. S. 2003. Fundamentals of heat exchanger design. New Jersey: John Wiley \& Sons. $976 \mathrm{p}$.

RSN 156-94 Statybine klimatologija [Climatology of buildings]. Vilnius, 1995. $33 \mathrm{p}$.

STR 2.01.09:2005 Pastatu energinis naudingumas. Energinio naudingumo sertifikavimas [Energy performance of buildings. Energy performance certification]. Vilnius: Ministry of Environment of the Republic of Lithuania, 2005.

STR 2.05.01:2005 Pastatu atitvaru šilumine technika [Thermal technique of building envelopes]. Vilnius: Ministry of Environment of the Republic of Lithuania, 2005.

STR 2.09.04:2008. Pastato šildymo sistemos galia. Šilumos poreikis šildymui [Power of the building heating system. Energy consumption for the heating]. Vilnius: Ministry of Environment of the Republic of Lithuania, 2008.

Švenčianas, P.; Adomavičius, A. 2011. Inžinerine termodinami$k a$ [Engineering Thermodynamics]. Kaunas: Technologija. 310 p. http://dx.doi.org/10.5755/e01.9786090200858

Venckus, N.; Bliūdžius, R.; Endriukaityte, A.; Parasonis, J. 2010. Research of low energy house design and construction opportunities in Lithuania, Technological and Economic Development of Economy 16(3): 541-554 http://dx.doi.org/10.3846/tede.2010.33

Yang, L.; Wan, K. K. W.; Li, D. H. W.; Lam, J. C. 2011. A new method to develop typical weather years in different climates for building energy use studies, Energy 36(10): $6121-6129$. http://dx.doi.org/10.1016/j.energy.2011.07.053

Nerijus VENCKUS. A PhD student of Civil Engineering, researcher at the Laboratory of Thermal Building Physics of the Institute of Architecture and Construction, Kaunas University of Technology. Research interests: unsteady heat transfer, thermal energy balance of buildings.

Raimondas BLIŪDŽIUS. Doctor, Head at the Laboratory of Thermal Building Physics at the Institute of Architecture and Construction, Kaunas University of Technology. Research interests: thermal processes in buildings, thermal and hydro properties of building materials and elements.

Jurga PODERYTE். A PhD student of Civil Engineering at Faculty of Civil Engineering and Architecture, Department of Building Materials, Kaunas University of Technology, Lithuania. Research interests: heating, ventilating and air conditioning.

Arūnas BURLINGIS. Doctor, Senior research worker of the Laboratory of Thermal Building Physics at the Institute of Architecture and Construction, Kaunas University of Technology. Research interests: thermal techniques in buildings. 